\title{
¿Qué modelos de enseñanza se pueden encontrar en las clases de biología en la escuela secundaria?
}

Zapata, Rocío de los Milagros ${ }^{1}$

Recibido: 22/09/2016

Aprobado: 12/10/2016

\section{Resumen}

El siguiente trabajo tiene como objetivo poner en discusión el desarrollo de las clases de biología en la escuela secundaria, poniendo la mirada en la práctica docente a la hora de organizar y desenvolver las clases. Para esto, tomaré como referencia los enfoques o modelos de enseñanza de la ciencia, a partir de realizar una indagación de los diversos autores y su correspondiente descripción. Como resultado de la exploración realizada se releva en los especialistas un acuerdo en encontrar clases que se correlacionan con el enfoque tradicional, o mezclas de los modelos que generan un hibrido en la práctica; junto con motivos explícitos o implícitos en cada docente que Ilevan a la utilización intencional o no del modelo. Esta problematización de la práctica, es preliminar a un trabajo de investigación que incluirá el estudio de casos concretos de docentes en biología y sus clases, a realizar posteriormente.

Palabras clave: enseñanza/aprendizaje de las ciencias, didáctica, modelos. 


\section{Summary}

The following research paper aims to discuss the development of biology classes in high school level, to shed some light into teaching practice when organizing and developing lessons. For this, I will take as a reference the approaches or models of teaching science, having as a starting point an inquiry into the various authors and their corresponding description on this subject. The gathered data is expected to pinpoint the agreement of some specialists on finding classes that correlate with the traditional approach, or mixtures that generate a hybrid model in practice; with explicit or implicit in each educational reason that lead to the intentional use or model. This problematized practice is preliminary to a research work that will include the study of specific cases of biology teachers and their classes to be performed later.

Keywords: teaching / learning science, teaching, models. 